\title{
Ocena przydatności elementów Web 2.0 na stronach internetowych bibliotek akademickich $w$ świetle badań ankietowych
}

\section{Wprowadzenie}

O becnie niezwykle modne stało się używanie terminu Web 2.0 na określenie nowych koncepcji i sposobów tworzenia zasobów sieciowych. Choć jeszcze do niedawna temat ten był podejmowany głównie przez fascynatów i futurologów Internetu, to jego popularyzacja sprawiła, że w wielu różnych dziedzinach życia i nauki pojawiły się pojęcia, próbujące uwydatnić istnienie tych nowych tendencji także w ich sferze (Biznes 2.0, Prawo 2.0, Kultura 2.0, Biblioteka 2.0). Entuzjastyczne przyjęcie współczesnych trendów konstruowania serwisów internetowych wywołało jednak także dyskusje dotyczące istoty tego zjawiska. W wielu środowiskach zaczęto się zastanawiać, czy jest to tylko przemijająca moda, czy raczej przełom, który na trwałe zmieni Internet. Niniejszy artykuł jest próbą przybliżenia i scharakteryzowania „Internetu drugiej generacji” (Web 2.0) oraz przedstawienia wyników badań ankietowych dotyczących obecności jego elementów na stronach WWW bibliotek.

* Studentka II roku uzupełniających studiów magisterskich informacji naukowej i bibliotekoznawstwa w Instytucie Informacji Naukowej i Bibliologii Uniwersytetu Mikołaja Kopernika w Toruniu. 


\section{Cechy charakterystyczne Web 2.0}

Termin „Internet drugiej generacji” oznacza nowy nurt konstruowania witryn internetowych, który został stworzony w celu zastąpienia znanej dotychczas tradycyjnej metody stosowanej w tej dziedzinie, określanej mianem Web 1.0. Obecnie przez pojęcie Web 2.0 rozumie się zbiór założeń ${ }^{1}$ dotyczących tworzenia stron WWW oraz innych aplikacji, które mogą działać bez dostępu do Internetu i pozwalają na interakcję i aktywne uczestnictwo użytkowników. Najczęściej jednak Web 2.0 definiuje się poprzez wyliczenie jego cech charakterystycznych, takich jak:

a) interaktywność, która polega na wykorzystywaniu interaktywnych technik tworzenia stron;

b) mechanizm wiki, umożliwiający użytkownikom edytowanie, modyfikowanie i dodawanie nowych treści do serwisu internetowego za pomocą przeglądarki internetowej;

c) istnienie więzi społecznościowych i możliwość tworzenia grup, nawiązywania kontaktów między internautami (np. serwisy typu Nasza Klasa, My Space, Facebook);

d) współtworzenie i współdzielenie, czyli łatwa wymiana informacji, aktywne uczestnictwo czy chociażby możliwość oceny i komentowania treści przez użytkowników;

e) ciągła wersja beta (serwisy są nieprzerwanie w fazie tworzenia);

f) łamanie schematów i istniejących zasad, dzięki czemu serwisy w tej konwencji tworzą nową wartość, dając upust kreatywności ich twórców;

g) zasada „to czego chcę i kiedy chcę”, która oznacza, że użytkownik może sam decydować, z jakich treści i w jakiej formie korzysta (np. kanały RSS, za pomocą których przesyłane są nagłówki wiadomości z witryn subskrybowanych przez użytkownika);

h) szybkość powstawania serwisów - wystarczy mieć dobry pomysł i wdrożyć go dzięki istniejącym, dość łatwym w obsłudze technologiom (generalnie koszt uruchomienia serwisu jest niski, jednak wraz ze wzrostem liczby użytkowników i multimediów wykorzystywanych w witrynie może znacząco wzrosnąć (np. YouTube.com) ${ }^{2}$.

1 B. Jaskowska, A. Dudczak, Library 2.0 - rewolucja i przełom czy kolejny etap rozwoju współczesnego bibliotekarstwa?, „Przegląd Biblioteczny” 2007, nr 3, s. 355.

${ }^{2}$ A. Leniek, Web 2.0. W: I-słownik.pl - Słownik slangu informatycznego [on-line] 
Bez wątpienia wśród cech sieci drugiej generacji wyróżnić można trzy kategorie ${ }^{3}$. Do cech technicznych należą m.in. wykorzystanie mechanizmu wiki, weblogów, udostępnianie interfejsów XML, pozwalających innym stronom i programom na korzystanie z danych Web 2.0 (przede wszystkim przez RSS i Atom) oraz używanie nowych technologii. Wśród cech społecznych należy wyróżnić generowanie treści przez użytkowników, stosowanie folksonomii, tworzenie się wokół serwisów rozbudowanych społeczności, wykorzystanie kolektywnej inteligencji oraz otwartych licencji, takich jak Creative Commons czy GNU GFDL. W grupie trzeciej można wyróżnić elementy odnoszące się do wyglądu stron mieszczących się w konwencji Web 2.0, a więc pastelowe barwy, gradienty, wszelkie zaokrąglenia, duże czcionki oraz efekt tzw. „mokrej podłogi” polegający na wyraźnym lustrzanym odbiciu.

Według Marii Miller i Elżbiety Mroczek, Internet drugiej generacji to Internet interaktywny, umożliwiający tworzenie grup i sieci znajomych, a poprzez to pozwalający na wyszukiwanie danych, ich ocenę, sugerowanie odnośników i samodzielne umieszczanie treści w sieci. Aspektem kluczowym tego zjawiska jest jednak zaangażowanie samych użytkowników w tworzenie zawartości serwisów, łatwość obsługi i popularyzacja otwartych standardów. Nie chodzi tu więc o stosowanie nowoczesnych, nieznanych dotąd technologii informatycznych, a jedynie o zmianę podejścia do samego Internetu oraz możliwość współtworzenia witryn i serwisów przez użytkowników ${ }^{4}$.

Za twórcę i popularyzatora pojęcia Web 2.0 uważa się Tima O’Reilly, który w 2004 r., podczas konferencji zorganizowanej przez O’Reilly Media i MediaLive International na temat nowych technik internetowych, opisał i nazwał zjawisko Internetu drugiej generacji. W swoim artykule What is Web 2.0? 0’Reilly podkreślił, że nie można wskazać ostrych granic tego nowego trendu, lecz jedną z ważniejszych cech Web 2.0 jest postrzeganie Internetu jako platformy ${ }^{5}$.

[dostęp 28 lutego 2009]. Dostępny w World Wide Web: http://www.i-slownik.pl/ 1,1894,web,2,0.html.

3 Web 2.0 [on-line]. Portal Webmaster.pl [dostęp 28 lutego 2009]. Dostępny w World Wide Web: http://www.webmaster.nietykalni.biz/content/view/373/40/.

${ }^{4}$ M. Miller, E. Mroczek, Profil użytkownika i inne elementy Web $2.0 \mathrm{w}$ bibliotekach cyfrowych. Biuletyn EBIB [on-line] 2007, nr 88 [dostęp 28 lutego 2009]. Dostępny w World Wide Web: http://www.ebib.info/2007/88/a.php?miller_mroczek.

5 T. O’Reilly, What is Web 2.0? [on-line]. O’Reilly Media, Inc. [dostęp 28 lutego 


\section{Biblioteka 2.0}

$\mathrm{W}$

raz z upowszechnieniem się zjawiska Web 2.0 i jego narzędzi w wielu dziedzinach życia pojawiły się nowe określenia, próbujące uwydatnić istnienie tego trendu także w ich sferze. Jednym z takich terminów jest Biblioteka 2.0 (ang. Library 2.0). Przez to pojęcie rozumiany jest nowy pomysł wykorzystania technologii w bibliotekarstwie, pozwalający użytkownikowi biblioteki porzucić typową do tej pory bierną rolę „petenta" i podjąć zadania projektanta czy moderatora ${ }^{6}$. Według Jacka Manessa, bibliotekarza Gemmill Engineering Library w Boulder (Kolorado), autora tekstu Biblioteka 2.0 w teorii: co Web 2.0 oznacza dla bibliotek, koncepcja biblioteki drugiej generacji polega na „zastosowaniu interaktywnych, współtworzonych oraz multimedialnych technologii sieciowych do udostępniania w Internecie bibliotecznych zasobów i usług"7. Stwierdzenie Manessa opiera się na założeniu, że Biblioteka 2.0 jest skoncentrowana na użytkowniku, oferuje mu doświadczenie o charakterze multimedialnym, tworzy kapitał społeczny, a także jest innowacyjna społecznie ${ }^{8}$.

Na nieco inny kontekst terminu Biblioteka 2.0 wskazuje polska wersja „Wikipedii”, która podaje, że tą nazwą określa się „taki model biblioteki, w którym realizacja tradycyjnych procesów bibliotecznych, projektowanie i udostępnianie nowych usług informacyjnych oraz kształtowanie zasobu biblioteki odbywa się w ścisłej współpracy bibliotekarzy i czytelników ${ }^{9}$.

Jak dowodzą zaprezentowane definicje, Bibliotekę 2.0 można pojmować w dwojaki sposób. W szerszym znaczeniu rozumiana jest ona przede wszystkim jako zmiana nastawienia do użytkownika biblioteki i umożliwienie mu podejmowania większej liczby działań z nią związanych, zarówno bezpośrednio, jak i z wykorzystaniem nowych technologii. W węższym znaczeniu termin ten obejmuje tylko czynności, jakie może wykonać

2009]. Dostępny w World Wide Web: http://www.oreillynet.com/pub/a/oreilly/tim/ news $/ 2005 / 09 / 30 /$ what-is-web-20.html?page=1.

${ }^{6}$ M. Casey, Working Towards a Definition of Library 2.0. Library Crunch [on-line] 2005, no. 10 [dostęp 28 lutego 2009]. Dostępny w World Wide Web: http://librarycrunch. com/2005/10/working_towards_a_definition_o.html.

7 A. Koszowska, Jack Maness o teorii Biblioteki 2.0 oraz o tym, co Web 2.0 oznacza dla bibliotek. Biuletyn EBIB [on-line] 2007, nr 85 [dostęp 28 lutego 2009]. Dostępny w World Wide Web: http://www.ebib.info/2007/85/a.php?koszowska.

8 Tamże.

${ }_{9}$ Biblioteka 2.0.W: Wikipedia. Wolna Encyklopedia [on-line] [dostęp 28 lutego 2009]. Dostępny w World Wide Web: http://pl.wikipedia.org/wiki/Biblioteka_2.0. 
użytkownik za pośrednictwem sieci internetowej. Także i w tym przypadku niezbędna jest zmiana statusu czytelnika - z biernego użytkownika na aktywnego współtwórcę i decydenta. W praktyce działanie to sprowadza się do wykorzystania przez bibliotekę typowych narzędzi Web 2.0, jakimi są wszelkiego rodzaju komunikatory i czaty, media strumieniowe (np. filmy instruktażowe, prezentacje), weblogi, wikipedie, sieci społeczne, kanały RSS, tagi czy kombinacje tych narzędzi (ang. mashups) ${ }^{10}$.

\section{Badania ankietowe dotyczące elementów Web 2.0 obecnych na stronach bibliotek}

W celu zbadania obecności i przydatności poszczególnych elementów Internetu drugiej generacji na stronach internetowych bibliotek, a także oceny ogólnej znajomości tego nowego zjawiska wśród młodzieży akademickiej przeprowadzono ankietę wśród 100 studentów Uniwersytetu Mikołaja Kopernika w Toruniu. Jej celem szczegółowym była weryfikacja ogólnego stosunku czytelników do bibliotek oraz zbadanie częstotliwości korzystania z ich zasobów. Przeprowadzona analiza posłużyła następnie do stwierdzenia, czy potrzeba użytkowania Web 2.0 uzależniona jest bezpośrednio od częstotliwości korzystania z biblioteki. $\mathrm{W}$ tym celu oceniono przydatność poszczególnych elementów Web 2.0 na stronach internetowych kilku wybranych bibliotek akademickich. Kolejnym celem badań było oszacowanie stopnia znajomości elementów Web 2.0 przez użytkowników bibliotek oraz określenie stosunku czytelników do jego poszczególnych narzędzi.

Do udziału w ankiecie zakwalifikowano osoby studiujące stacjonarnie na pierwszym i drugim roku uzupełniających studiów magisterskich różnych kierunków. Wybór takiej grupy nie był przypadkowy, miał bowiem umożliwić porównanie ewaluacji potrzeb informacyjnych dokonującej się na skutek rozwoju edukacyjnego badanych. Wśród respondentów znaleźli się przedstawiciele obydwu płci. Ostatecznie w badaniu wzięło udział 59 kobiet i 41 mężczyzn (53\% z pierwszego i $47 \%$ z drugiego roku studiów), reprezentujących 29 różnych kierunków kształcenia (m.in. biologii, chemii, prawa, administracji, ekonomii, zarządzania, fizy-

${ }^{10}$ A. Koszowska, dz. cyt. 
ki, matematyki, informatyki, filologii polskiej i obcych, pedagogiki, turystyki, filozofii, astronomii).

Kwestionariusz ankiety zawierał 11 pytań dotyczących częstotliwości korzystania z bibliotek, używania ich stron internetowych, rodzaju wykorzystywanych źródeł informacji oraz ogólnego nastawienia do technologii Web 2.0. Respondenci zostali również poproszeni o ocenę narzędzi Web 2.0 (takich jak: weblogi, kanały RSS, wikipedie, tagi, fora itp.) pod względem ich przydatności na stronach WWW bibliotek oraz o sformułowanie wniosków dotyczących użyteczności i wiarygodności różnych źródeł informacji dostępnych w Internecie.

Pierwsze wyniki badań dowiodły dużej aktywności w zakresie użytkowania bibliotek: połowa badanych korzysta z jej zbiorów kilka razy w miesiącu. 29 respondentów deklaruje także częstsze odwiedziny. 19 studentów odwiedza biblioteki sporadycznie, a 2 w ogóle nie odczuwa takiej potrzeby. Szczegółowe zakresy częstotliwości odwiedzin oraz liczbę odwiedzających prezentuje wykres 1 .

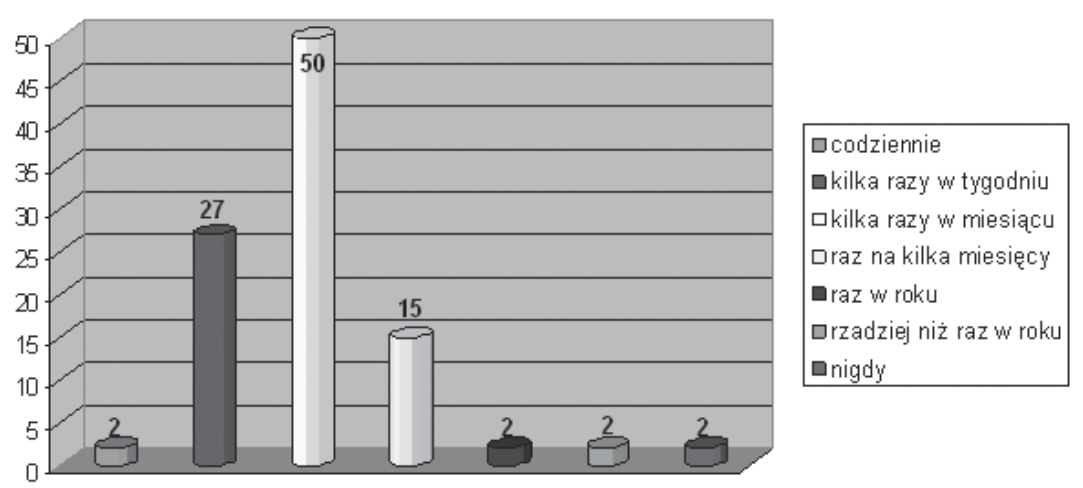

Wykres 1. Częstotliwość korzystania z bibliotek przez ankietowanych Źródło: opracowanie własne.

W odpowiedzi na pytanie o rodzaj wykorzystywanych źródeł informacji $81 \%$ respondentów wskazało książki naukowe, $80 \%$ podręczniki i skrypty, $40 \%$ literaturę rozrywkową, a 31\% czasopisma naukowe. Kilku studentów wymieniło także kolekcje graficzne i kartograficzne, stare druki, bazy danych i czasopisma popularne. Rodzaje najczęściej wykorzystywanych źródeł obrazuje wykres 2. 


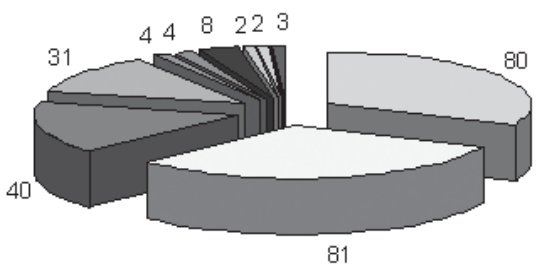

\begin{tabular}{|l|}
\hline ksiażki naukowe \\
$\square$ podręcz nik, skrypty \\
$\square$ ksiażki czytane dla rozryw'k \\
$\square$ czas opisma naukowe \\
$\square$ czas opisma czytane dla rozrywkiki \\
$\square$ bazy darych \\
$\square$ zbiory kartograficzne \\
$\square$ zbiory graficzne \\
$\square$ stare druki \\
$\square$ zbiory muzyczne \\
$\square$ DŻs \\
$\square$ inne
\end{tabular}

Wykres 2. Źródła informacji najczęściej wykorzystywane przez studentów Źródło: opracowanie własne.

Jak wykazały badania, większość studentów korzysta z bibliotek wydziałowych (87\%) oraz Biblioteki Uniwersyteckiej (85\%). Ponad połowa $\mathrm{z}$ nich (56\%) preferuje przy tym zasoby tradycyjne, a jedynie $13 \%$ dostrzega przydatność treści cyfrowych. Stosunkowo rzadko studenci zaglądają na strony internetowe bibliotek. $44 \%$ korzysta z nich kilka razy w miesiącu, ale aż $26 \%$ częściej. Tylko $6 \%$ wszystkich badanych nie wykorzystuje tej możliwości w ogóle.

Podsumowując kwestie dotyczące częstotliwości odwiedzania bibliotek, można sformułować wniosek, że respondenci biorący udział w badaniach stanowią grupę aktywnych użytkowników bibliotek, a w poszukiwaniu odpowiednich źródeł informacji korzystają z bibliotek różnych typów. Średnia liczba bibliotek odwiedzanych przez jednego ankietowanego wynosi 2,42, przy czym u kobiet wskaźnik ten jest znacznie wyższy niż u mężczyzn (2,54 - dla kobiet, 2,24 - dla mężczyzn). Ponadto kobiety deklarują także częstsze odwiedzanie stron internetowych bibliotek. Najbardziej aktywnymi użytkownikami bibliotek okazują się studenci pierwszego roku studiów magisterskich. Jak dowiodły badania, korzystają oni z usług bibliotek, zarówno tych tradycyjnych, jak i elektronicznych, znacznie częściej niż ich starsze koleżanki i koledzy.

Ponieważ najważniejszym zadaniem ankietowanych była ocena przydatności poszczególnych narzędzi Web 2.0, kolejne pytania kwestionariusza dotyczyły tego zagadnienia. Na stronach WWW bibliotek studenci rozważali zastosowanie następujących elementów:

a) kontakt z bibliotekarzem za pomocą komunikatorów lub czatu;

b) kontakt z biblioteką przez e-mail lub formularz WWW; 
c) media strumieniowe (np. krótkie filmy instruktażowe lub prezentacje informujące, w jaki sposób korzystać z zasobów biblioteki);

d) kanał RSS (do przesyłania nagłówków nowych wiadomości ukazujących się w serwisie biblioteki);

e) weblog użytkowników biblioteki (możliwość jego prowadzenia na stronie biblioteki);

f) weblog bibliotekarzy (informacje na temat pracy biblioteki zamieszczane przez bibliotekarzy);

g) forum użytkowników;

h) wikipedie (miniencyklopedie tworzone przez użytkowników bądź bibliotekarzy);

i) tagi (hasła rzeczowe, słowa kluczowe opisujące daną publikację, tworzone przez użytkowników);

j) serwis dla użytkowników biblioteki, w tym możliwość tworzenia własnego profilu;

k) kursy przez Internet;

l) możliwość sugerowania przez użytkownika tytułu książki, którą należy zakupić;

m) rozrywka (np. gry edukacyjne) dostępna na stronie biblioteki;

n) możliwość dodawania przez użytkowników biblioteki informacji o wystawach, wydarzeniach kulturalnych w odpowiednim dziale serwisu;

o) tworzenie przez czytelników biblioteki zbioru linków (odnośników) do ciekawych stron;

p) podstrony internetowe biblioteki dedykowane dzieciom, młodzieży (gry edukacyjne, ćwiczenia, artykuły, recenzje książek).

Już bardzo ogólny wgląd w wyniki badań pozwolił zauważyć, że respondenci posiadali podstawową wiedzę o zjawisku, jakim jest Web 2.0: aż $82 \%$ z nich należało do społeczności internetowych, 43\% aktywnie uczestniczyło w forach, 19\% tworzyło lub modyfikowało artykuły w wikipediach, a 11\% prowadziło własne weblogi. Ocena poszczególnych narzędzi Web 2.0 potwierdziła te spostrzeżenia. Jej szczegółowe wyniki przedstawiono na wykresie 3.

Za niezbędne elementy każdej strony bibliotecznej respondenci uznali możliwość dodawania tagów opisujących daną publikację (39\%) oraz kontakt z biblioteką za pomocą poczty elektronicznej lub formularza WWW (32\%). Dla 16\% studentów takim elementem były wikipedie, a dla 15\% e-learning (zwłaszcza kursy wyszukiwania informacji). 13\% badanych 
podkreśliło możliwość sugerowania publikacji do zakupu, a 12\% wskazało podstrony internetowe biblioteki (dedykowane dzieciom i młodzieży) jako najbardziej nieocenione z punktu widzenia użytkownika Web 2.0.

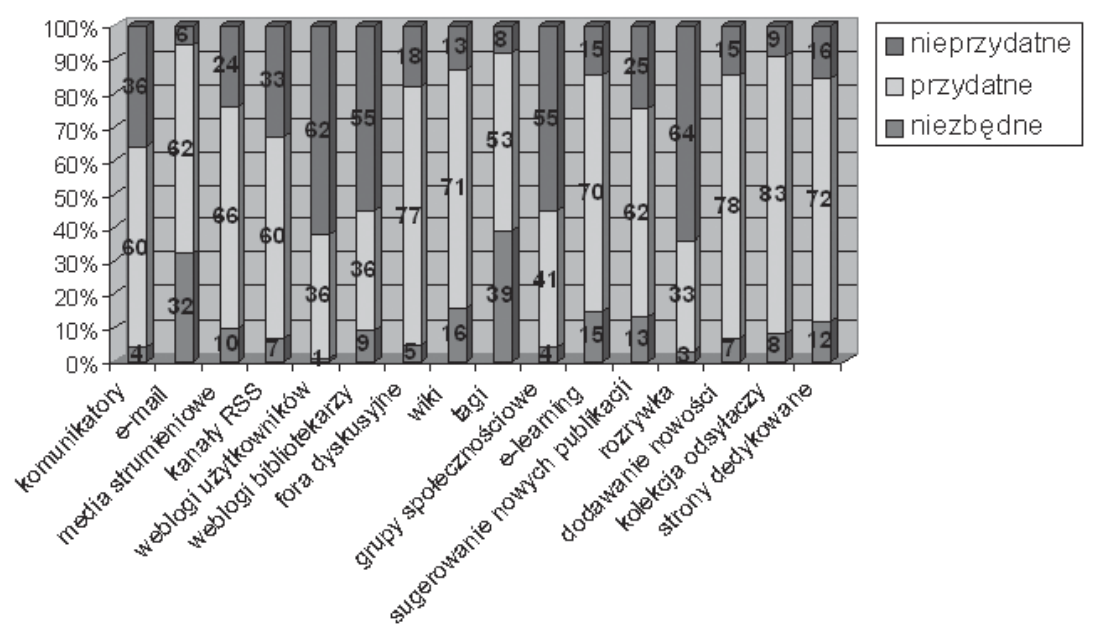

Wykres 3. Ocena przydatności poszczególnych elementów Web 2.0 na stronach internetowych bibliotek

Źródło: opracowanie własne.

Ponad połowa studentów zdecydowała, że narzędzia takie, jak komunikatory, media strumieniowe, kanały RSS, fora, możliwość dodawania przez użytkowników informacji o wydarzeniach kulturalnych oraz kolekcje linków, mogą być przydatne i są mile widziane na stronach bibliotek, ale są mniej użyteczne niż te wymienione w grupie powyżej.

Ankietowani wyróżnili także trzecią grupę narzędzi Web 2.0, które zostały uznane za zbędne lub nieprzydatne. Wśród nich wymieniono rozrywkę (64\% odpowiedzi), weblogi użytkowników (62\%), weblogi bibliotekarzy (55\%) i możliwość tworzenia internetowej społeczności biblioteki (55\%).

Aby dokonać porównania wyników ankiety i oszacować wartość poszczególnych elementów Web 2.0, każdemu typowi odpowiedzi przyporządkowano odpowiednią punktację:

- odpowiedź „niezbędne” - 2 punkty,

- odpowiedź „przydatne” - 1 punkt,

- odpowiedź „nieprzydatne” - minus 1 punkt. 
O ostatecznej ocenie danego narzędzia zdecydowała zatem suma wszystkich punktów. Sposób obliczania sumarycznej wartości danego elementu demonstruje poniższy przykład:

Zadaniem 100 studentów była ocena komunikatorów internetowych. $\mathrm{W}$ jej rezultacie:

- 4 studentów oceniło je jako element niezbędny (2 punkty za każdą odpowiedź),

- 60 studentów jako element przydatny (1 punkt za każdą odpowiedź),

- 36 studentów jako element nieprzydatny ( -1 punkt za każdą odpowiedź).

Ostatecznie na sumaryczną ocenę komunikatorów złożyły się oceny cząstkowe:

(4 studentów $\times 2$ punkty $)+(60$ studentó $\mathrm{w} \times 1$ punkt $)+$

$+[36$ studentó $\mathrm{w} \times(-1$ punkt $)]=32$

Poniżej zaprezentowano ocenę punktową poszczególnych elementów Web 2.0 na stronach WWW bibliotek wytypowanych do badania.

Tabela 1. Ocena punktowa narzędzi Web 2.0

\begin{tabular}{|l|c|c|c|c|}
\hline \multicolumn{1}{|c|}{ Rodzaj narzędzia } & Niezbędne* & Przydatne & $\begin{array}{c}\text { Nieprzy- } \\
\text { datne }\end{array}$ & $\begin{array}{c}\text { Suma } \\
\text { punktów }\end{array}$ \\
\hline Komunikatory & 8 & 60 & 36 & 32 \\
\hline E-mail & 64 & 62 & 6 & 120 \\
\hline Media strumieniowe & 20 & 66 & 24 & 62 \\
\hline Kanały RSS & 14 & 60 & 33 & 41 \\
\hline Weblogi użytkowników & 2 & 36 & 62 & -24 \\
\hline Weblogi bibliotekarzy & 18 & 36 & 55 & -1 \\
\hline Fora dyskusyjne & 10 & 77 & 18 & 69 \\
\hline Wikipedie & 32 & 71 & 13 & 90 \\
\hline Tagi & 78 & 53 & 8 & 123 \\
\hline Społeczność internetowa & 8 & 41 & 55 & -6 \\
\hline
\end{tabular}


Tabela 1. Ocena punktowa narzędzi Web 2.0 (ciąg dalszy)

\begin{tabular}{|l|c|c|c|c|}
\hline \multicolumn{1}{|c|}{ Rodzaj narzędzia } & Niezbędne* & Przydatne & $\begin{array}{c}\text { Nieprzy- } \\
\text { datne }\end{array}$ & $\begin{array}{c}\text { Suma } \\
\text { punktów }\end{array}$ \\
\hline E-learning & 30 & 70 & 15 & 85 \\
\hline Sugerowanie nowych publikacji & 26 & 62 & 25 & 63 \\
\hline Rozrywka & 6 & 33 & 64 & -25 \\
\hline Dodawanie nowości & 14 & 78 & 15 & 77 \\
\hline Kolekcje odsyłaczy & 16 & 83 & 9 & 90 \\
\hline Strony dedykowane & 24 & 72 & 16 & 80 \\
\hline
\end{tabular}

* Na zawartość kolumny „Niezbędne” składa się liczba oddanych głosów × 2 punkty.

Źródło: opracowanie własne.

Jak dowodzą dane z tabeli 1, za najcenniejsze elementy Web 2.0 na stronach internetowych bibliotek zostały uznane: możliwość dodawania tagów do opisu dokumentów w katalogu OPAC (123 punkty), kontakt z biblioteką poprzez e-mail lub formularz WWW (120 punktów), wikipedie oraz kolekcje odnośników (po 90 punktów). Mniejszą popularnością cieszyły się kursy e-learningowe (85 punktów), strony dedykowane dzieciom lub młodzieży (80 punktów) oraz możliwość generowania wiadomości o wydarzeniach kulturalnych (77 punktów). W grupie narzędzi uznanych za całkowicie nieprzydatne znalazły się z kolei: rozrywka ( -25 punktów), weblogi użytkowników ( -24 punkty), weblogi bibliotekarzy ( -1 punkt) oraz możliwość tworzenia internetowej społeczności użytkowników ( -6 punktów).

Badania wykazały, że częstotliwość odwiedzin bibliotek i ich stron internetowych nie wpłynęła na postrzeganie przydatności elementów Web 2.0. Osoby najbardziej aktywne pod tym względem oceniły użyteczność poszczególnych narzędzi podobnie jak reszta respondentów. Aż 37\% z nich uznało możliwość dodawania tagów do opisu dokumentu za niezbędną, 27\% dodało do tej grupy kontakt z biblioteką za pomocą e-maila oraz formularza WWW, a 20\% media strumieniowe. $66 \%$ z tych osób negatywnie oceniło obecność rozrywki na stronie biblioteki oraz blogi użytkowników i serwisy społecznościowe (po 58\% odpowiedzi). Ich opinie nie różniły się zatem od stanowiska pozostałych badanych. 
Kolejnym zadaniem stojącym przed uczestnikami ankiety była ocena źródeł informacji dostępnych w Internecie pod względem ich przydatności i wiarygodności. Udzielając odpowiedzi na pytanie „Jak oceniasz przydatność i wiarygodność wikipedii (encyklopedii tworzonych przez użytkowników)?", respondenci mieli do wyboru następujące możliwości:

1) przydatność źródła:

- niezbędne,

- przydatne,

- nieprzydatne,

2) wiarygodność źródła:

- wiarygodne,

- niewiarygodne.

Wyniki uzyskane na podstawie odpowiedzi na wyżej zadane pytanie przedstawiono na wykresie 4.

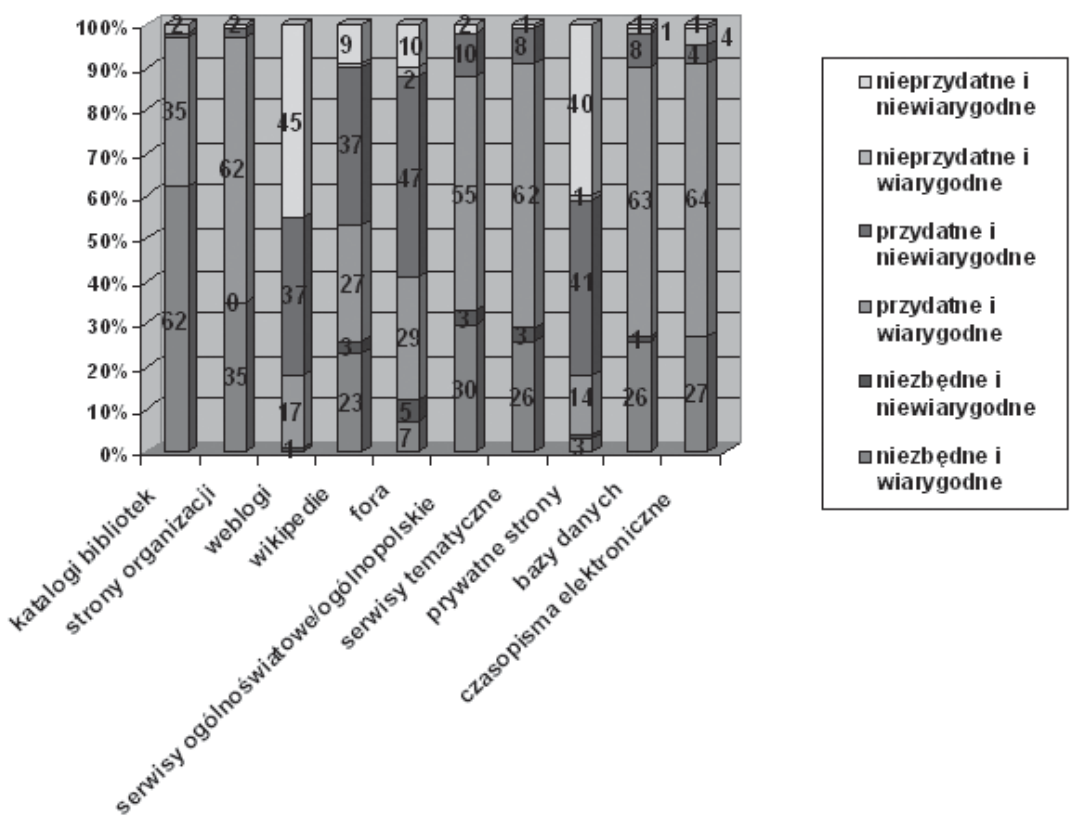

Wykres 4. Ocena przydatności i wiarygodności wybranych źródeł informacji dostępnych on-line

Źródło: opracowanie własne. 
Jak widać, dla większości badanych (62\%) najbardziej niezbędnym i wiarygodnym źródłem informacji okazały się katalogi bibliotek dostępne on-line. Tylko kilku studentów zaliczyło do tej grupy fora oraz prywatne strony internautów.

W grupie przydatnych i wiarygodnych źródeł informacji znalazły się czasopisma elektroniczne (64\%), bazy danych (63\%), serwisy tematyczne (ang. subject gateways) i strony instytucji i organizacji (po 62\%) oraz ogólnoświatowe i ogólnopolskie serwisy informacyjne (55\%).

Trzecią grupę źródeł, wyróżnioną przez ankietowanych, stanowiły elementy nieprzydatne i niewiarygodne, takie jak weblogi (45\% odpowiedzi) i prywatne strony internautów (40\%).

Respondenci wyodrębnili także grupę przydatnych, ale niewiarygodnych źródeł informacji, do których zaliczyli fora i wikipedie (odpowiednio 47 i $37 \%$ ).

Na podkreślenie zasługuje fakt, że mimo ogromnej różnorodności źródeł informacji dostępnych w Internecie na miano rzetelnych zasłużyły przede wszystkim te, które tworzone są przez specjalistów informacji i od lat posiadają ugruntowaną pozycję wśród użytkowników bibliotek, a więc katalogi, bazy danych, serwisy tematyczne i czasopisma elektroniczne. Bez wątpienia dowodzi to celowości ich tworzenia.

Badano też kwestię cytowania źródeł elektronicznych tworzonych przez internautów. Okazuje się, że aż 49\% badanych studentów korzysta w swoich pracach (esejach, pracach zaliczeniowych, licencjackich, magisterskich) ze źródeł tworzonych przez innych użytkowników sieci, ale nie powołuje się na nie. Czyni tak jedynie 31\% ankietowanych. 20\% osób deklaruje również, że w ogóle nie korzysta ze źródeł elektronicznych, ale aż 48\% wszystkich respondentów zdaje sobie sprawę, że wiarygodność i rzetelność informacji pochodzących z wikipedii, forów, grup dyskusyjnych i weblogów jest kwestionowana przez nauczycieli akademickich.

\section{Podsumowanie}

W yniki przeprowadzonych badań dowodzą, że narzędzia Internetu drugiej generacji, które mogą być wykorzystane na stronach bibliotek, są postrzegane przez studentów jako przyjazne, łatwe, użyteczne i wygodne w obsłudze. Adaptacja tych elementów i budowanie na ich podstawie Biblioteki 2.0 przyczynia się do zmiany stereotypowego obrazu biblioteki - 
z powolnej, obojętnej, nieprzyciągającej uwagi na przyjazną i przydatną dla użytkownika, bo pozwalającą na uczestnictwo i komunikację.

Mimo młodego wieku studenci wykazali się dużą świadomością ograniczeń w zakresie implementacji nowych trendów technologicznych $\mathrm{w}$ instytucjach takich jak biblioteki. Potrafili oni nie tylko dostrzec różnicę w jakości treści w serwisach tworzonych przez użytkowników sieci i tych konstruowanych przez specjalistów informacji, ale zauważyli także, że bezmyślne wprowadzanie pewnych elementów technologicznych na strony WWW bibliotek może zdecydowanie utrudniać pracę z ich witrynami, a nawet obniżać ich wiarygodność. Z tego powodu elementami, których obecność w serwisach bibliotek nie zyskała szczególnej aprobaty ze strony studentów, były weblogi czytelników i bibliotekarzy, fora czytelników oraz miejsca służące rozrywce.

Choć $\mathrm{w}$ badaniach nie dowiedziono korelacji między częstotliwością korzystania z biblioteki i jej serwisu a postrzeganiem i oceną narzędzi Web 2.0, należy pamiętać, że ankietowani deklarowali użytkowanie różnego typu bibliotek (wydziałowych, publicznych, cyfrowych itp.), które w swoim otoczeniu pełnią niekiedy bardzo odmienne funkcje. W przyszłości uzasadnione byłoby więc podjęcie badań nad obecnością narzędzi Web 2.0 na stronach różnego typu bibliotek i zweryfikowanie ich przydatności z punktu widzenia obsługiwanej przez nie kategorii użytkowników.

\section{An assessment of Web 2.0 usability elements on the websites of academic libraries. Results of a survey Abstract}

This paper aims to introduce the definition of Web 2.0 and results of survey conducted among the students of Nicolaus Copernicus University in Torun. The assessment of Web 2.0 elements made by inquired students has been presented. Utilization of the Internet tools pointed by responders as the most useful and functional can contribute to an efficiently built, user-friendly library website. Students revealed their critical attitude towards suggested solutions and positively appraised these, which can be implemented and successfully used in library websites. Moreover a general attitude towards Web 2.0, ways of using it in everyday life and perceiving the reliability and usefulness of different sources of information, that are accessible in the Internet, were investigated. 